38. Jones CT, Harding JE, Gu W, Lafeber HN 1988 Placental metabolism and endocrine effects in relation to the control of fetal and placental growth. In: Kunzel W, Jensen A (eds) The Endocrine Control of the Fetus. pp 213-222 39. Pilistine SJ, Moses AC, Munro HN 1984 Placental lactogen administration reverses the effect of low-protein diet on maternal and fetal serum somatomedin levels in the pregnant rat. Proc Natl Acad Sci USA 81:5853-5857

40. Mellor DJ 1984 Investigation of fetal growth in sheep. In: Nathanielsz PW (ed)
Animal Models in Fetal Medicine, Vol IV. Perinatology Press, Ithaca, NY, pp 149-173

41. Smith CA 1947 The effects of maternal undernutrition upon the newborn infant in Holland (1944-1945). J Pediatr 30:229-243

42. Stein Z, Susser M 1975 The Dutch famine 1944-45, and the reproductive process II. Interrelations of caloric rations and six indices at birth. Pediatr Res 9:76-83

\title{
Announcements
}

\section{Seeking Acute Cases of Rheumatic Fever and Sydenham's Chorea}

The Child Psychiatry Branch of the National Institute of Mental Health is seeking patients for a study of the course of psychologic symptoms accompanying Sydenham's chorea and rheumatic fever. Eligible patients should have had recent (within $2 \mathrm{mo}$ ) onset of rheumatic fever, continue to have symptoms, and be at least 6 y of age. This study will rate a variety of psychologic and psychiatric symptoms and link these symptoms to anti-CNS autoantibodies. The results will be important in defining the etiology of childhood-onset psychiatric disorders. Patients and their parents will be asked to travel at NIH expense to the NIMH in Bethesda, MD for an initial interview. Brief follow-up interviews will be conducted by telephone every 2 mo for 1 y. Serum samples ( $5 \mathrm{cc}$ ) will be obtained on four separate occasions. There will be no expense to the patient and no remuneration. Please call Dr. Susan Swedo at (301) 496-6081 or write: Dr. S. Swedo, Child Psychiatry Branch, NIMH, Bldg. 10, Room 6N240, 9000 Rockville Pike, Bethesda, MD 20892.

\section{ANNUAL MEETINGS}

The American Pediatric Society, The Society for Pediatric Research and The Ambulatory Pediatric Association will meet May 7-11, 1990; Anaheim Hilton \& Towers and Convention Center, Anaheim, CA.

Contact: APS or SPR: Association Headquarters, 2650 Yale Blvd., S.E., Suite 104, Albuquerque, NM 87106, (505) 764-9099 or 0068. APA: Ambulatory Pediatric Association, 6728 Old McLean Village, McLean, VA 22101, (703) 556-9222.

\section{Special Program in Nutrition for a Health Heart Developed for Grade School Children and Their Parents}

The J. David Gladstone Foundation of the University of California, San Francisco, has developed a heart healthy nutrition education curriculum for third grade students and their parents. This curriculum, called the Special Program in Nutrition (SPIN), consists of two manuals and a cookbook collection of low fat, low cholesterol recipes. The manuals contain an in-service program for teachers, 27 lessons for third grade students, seven lessons for fourth grade students, and a parents' program with 10 planned meetings.

The cost of the complete set is $\$ 35.00$; the two-volume curriculum and the cookbook may be purchased separately for $\$ 30.00$ and $\$ 10.00$, respectively. Add $6.5 \%$ California sales tax where applicable. For further information contact: The Gladstone Foundation Laboratories, 2550 23rd Street, P.O. Box 40608, San Francisco, CA 94140, (415) 826-7500. 